\title{
Considerations of Truth and Fact in Narrative Analysis
}

\author{
JEANANNE NICHOLS \\ University of Illinois Urbana-Champaign (USA)
}

A central understanding of narrative scholarship is that stories are ever in process, taking shape in each recounting according to the needs, purposes, and understandings of the teller. Sometimes participants share accounts that are incomplete or inaccurate, shrink from voicing their feelings, or silence their accounting altogether. In this study, I draw on difficult stories, shared by military bandswomen who endured a traumatic government investigation into their personal lives during the McCarthy era, to examine the distinctions between empirical facts and interpretive truth, trouble the linkage between objective and subjective ways of knowing, and consider the researcher's ethical responsibility when a participant hides the facts or refuses to voice their truths.

Keywords: narrative analysis, women's band, trauma, memory, US Air Force WAF

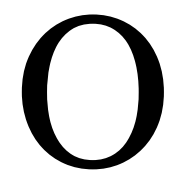

ver the past fifteen years, I have been engaged in a long-term project to document the history of the United States Air Force "Women in the Air Force (WAF)" military band, which existed from 1951 to 1961. In my quest for insight into the social and historical construction of women band musicians, I have conducted in-depth oral history interviews with more than 30 of the WAF bandswomen and collected over 2,00o primary source artifacts from personal and archival collections. In the process of sifting, sorting, compiling, and triangulating the large trove of data, I encountered several moments in which a participant's account contradicted other primary sources. Understandably, persons narrating events from more than a half century ago may sometimes struggle to accurately recall finer details, but in several testimonies, the discrepancies and silences warranted further examination.

The WAF bandswomen came of age in postwar America during the 1950s. Not content to immediately follow the accepted social path of marriage and family after high school, they joined the WAF, a program the US Air Force created to recruit and train enlisted women for non-combat jobs in response to its postwar labor

(C) Jeananne Nichols. The content of this article is the sole responsibility of the author. The ACT Journal and the Mayday Group are not liable for any legal actions that may arise involving the article's content, including, but not limited to, copyright infringement. 
shortage. In 1951, an all-WAF band was formed to assist with Air Force recruiting and public relations by performing public concerts. The band was an unqualified success. For over a decade, they toured extensively and performed in some of America's most famous venues, on network television, and at some of the nation's most prestigious public events. Yet, citing a lack of funds to continue its mission and noting that women just had not enlisted in the numbers needed, the Air Force deactivated the WAF Band in 1961.

Marilyn, ${ }^{1}$ an enlisted member of the band and conductor of the unit, had been a crucial eyewitness to the origins of the band, its early progress, and its transition to a full-fledged ensemble in the Air Force Bands organization. I interviewed her at the band's annual reunion ${ }^{2}$ in 2011. Marilyn was fun to talk to, fiercely open, but she struggled with dementia. Her choice to travel to the reunion alone had alarmed both her family and former bandmates. At one point in our conversation, when I asked her what year she married her husband, she became irritated and fished a card out of her wallet that contained the information. She explained that her children had made it for her because she got upset when she could not remember anniversaries and birthdays.

What follows is a portion of an interview transcript in which Marilyn recounted attending a conference with her unit commander, who was one of a small number of women in the Air Force that held the rank of Captain at that time. When I placed Marilyn's account of this trip alongside other primary source materials, it was obvious that her grasp of the facts had eroded with time and infirmity. In the passage that follows, the information in bold was incorrect:

[We went to] the National Band Masters Association meeting, and they were meeting in Arkansas, and it was for her as much as it was for me in that we were the only two women there with all the men. At that time, most of the Air Force band directors were warrant officers and things like that, and here comes in this female Captain (laughs). It wasn't very long after that conference that the other band directors began to get promoted (laughing) from warrant officers. But it was interesting, and of course I was the only female in the band playing, and I was playing tuba. And they made a publicity photo of that, which was in the $\mathbf{N a}$ tional Music Education Journal, of me and the male tuba player, which did a lot for proselytizing and getting out to musicians in schools and universities, women musicians, that there was a WAF Band. And after that we began to have quite a few people trying out... ${ }^{3}$

As this transcript segment demonstrates, even though several of Marilyn's facts are wrong, she is clear about what the experience meant to her. She is delighted at the male warrant officers' envy of her colleague's Captain's stripes and

Nichols, Jeananne. 2021. Considerations of truth and fact in narrative analysis. Action, Criticism, and Theory for Music Education 20 (4): 45-57. https://doi.org/10.22176/act20.4.45 
proud that her picture in a national magazine helped recruit professional caliber musicians to the band. Marilyn's diminished ability to remember specific facts alongside her clear recollection of her feelings points to a bifurcation in knowing between the "facts of what happened" and the "interpretation of what happened."

\section{Distinction Between Truth and Fact}

Narrative inquiry rests on a foundation of storied experience. Narrative researchers intentionally accede a certain authority to study participants, acknowledging their expertise in their own lives and prioritizing their meanings in the resulting scholarship. As LeCompte (1993) notes, "Research participants should have the first right to name reality, to articulate how social reality functions, and to decide how the issues are to be organized and defined" (13). But this "deference to a participant's accounting and interpreting of their experiences," Hodkinson and Smith (2005) warn, is not intended as a "methodological means to determine 'fact,' a term used here to indicate a knowable reality verifiable by empirical evidence" (924).

Blumenfeld-Jones (1995) makes a similar distinction, defining "truth" as "what happened in a situation (the truth of the matter)," then adopting the term fidelity to indicate "what [the experience] means to the teller of the tale (fidelity to what happened for that person)" (26). He observes, "Truth treats a situation as an object while fidelity is subjective. The object/subject distinction can become a test for the presence of fidelity and a warning for when fidelity is slipping over into truth" (26).

Notice that Hodkinson and Smith use the word fact to refer to the phenomena Blumenfeld-Jones labels as truth. Scholars writing about objective and subjective ways of knowing are not consistent in their definition of terms and use of labels across the literature, so to minimize confusion, for the purposes of this paper, the term fact refers to a knowable reality, verifiable by empirical evidence (with all the attendant postmodern caveats) and truth refers to the subjective, interpretive construction of meaning, as in "speaking your truth."

In their essay on the politics of evidence, Denzin and Giardina (2016) state, "Few critical ethnographers ... think in a language of evidence; they think instead about experience, emotions, events, and the politics of possibility" (3). Likewise, Stauffer (2014) offers that "Narrative scholarship is not about measuring the accuracy of detail, but rather about the constructing of selves and meanings and lives

Nichols, Jeananne. 2021. Considerations of truth and fact in narrative analysis. Action, Criticism, and Theory for Music Education 20 (4): 45-57. https://doi.org/10.22176/act20.4.45 
in a world where ambiguity is the normal state of affairs" (181). It would be a gross oversimplification to assert that Denzin and other narrative scholars do not care about the facts, but Steven Lubet, a professor at Northwestern's Pritzker School of Law, argues that the focused attention on the subjective creates conditions in which the ethnographer does not attend to the verity of participant stories, which in turn calls into question the usefulness of the narratives.

Lubet (2018) took exception to Alice Goffman's 2015 ethnography On the Run: Fugitive Life in an American City, a book critics hailed as "sociology at its best" and "a remarkable feat of reporting." 4 He found the vignettes implausible, inconsistent with his own experience as a defense lawyer in Chicago's criminal justice system. Lubet subsequently evaluated fifty ethnographic books and journal articles in urban sociology and assessed the authors' use of evidence in terms of sources, collection, presentation, and dependability in comparison to the standards for evidence in courts of law. He approved of scholars whose accuracy, candor, and documentation was substantive and chided others for the use of anonymous research participants, second-hand accounts, and the failure to check easy-to-verify facts.

There is some merit to Lubet's criticisms and proposed remedies. But in his enthusiasm to indict social science researchers, he does not satisfactorily wrestle with the complexities of human knowing and the convoluted way participants formulate the stories they share. A central tenet of narrative scholarship is that all stories are partial, performative, and in process. If, as narrativists contend, people construct and share stories from inextricably intertwined objective and subjective ways of knowing, then, as skeptics accuse, does the instability of one call into question the stability of the other? What does the lack of fact indicate about the truth, and conversely, what does a lack of truth indicate about the facts? The purpose of this paper is to examine these moments of tension, trouble the linkage between the objective and subjective in participant stories, and consider the researcher's ethical responsibility when a participant hides the facts or refuses to voice their truths. In my research, this phenomenon became most evident in interviews I conducted with WAF band members who endured the final six months of the band's existence.

\section{Curating Truth and Fact in Accounts of Trauma}

Two months before the planned deactivation of the WAF Band in August 1961, the bandswomen were subjected to an Air Force Office of Special Investigations (OSI) investigation into allegations of homosexuality among the members. It was not

Nichols, Jeananne. 2021. Considerations of truth and fact in narrative analysis. Action, Criticism, and Theory for Music Education 20 (4): 45-57. https://doi.org/10.22176/act20.4.45 
unusual for the WAF units to have discharges due to lesbianism-it was the McCarthy era ${ }^{5}$ after all-but this investigation was on a noticeably larger scale. The band members described it as a purge. Working from an old, resolved complaint, the OSI brought band members in one by one and re-interviewed them. They were told that other band members had named them as lesbian (which was often not true), questioned at length about their sexual and social histories, and ordered to name other lesbians in the unit. If the OSI could not substantiate the charge they wished to press, then the band member was charged with "associating with known lesbians," an easy case to make in a military band that traveled and lived together. The accused were told they had two options: accept a general discharge or contest the charges in court martial and be dishonorably discharged. The investigation was unjust and traumatic. Testimonial and archival evidence suggests that the investigation served to pre-empt the band's commander from leveraging public opinion or internal Air Force support to stop the planned deactivation of the band.

What follows are excerpts from interviews with three bandswomen-Doris, Grace, and Shirley-who were forced out of the service under these circumstances. Their stories of leaving the band are marked by rage, pain, and shame. Even as they chose to share their stories of that traumatic time in some fashion, each one curates the difficult facts and painful truths of their separation from the military differently.

\section{Doris: Denying the Facts}

I interviewed Doris in the early years (2007-2009) of the project. At that time, I was only aware that there had been an OSI investigation, but I did not know its extent and devastation. I only knew enough to carefully ask the neutral question that starts this part of the interview:

JN: Well, so how did your time with the WAF band come to an end?

Doris: My time was up ... I went out on a good note, but I was there to see what the others were going through and I didn't like it. It was hurtful, but we just keep on plugging away.

$\mathrm{JN}$ : At the time your enlistment went out, you knew that the band was going to be deactivated by that point?

Doris: They were in the process.

JN: So, you didn't wish to stay in the Air Force without the band?

Nichols, Jeananne. 2021. Considerations of truth and fact in narrative analysis. Action, Criticism, and Theory for Music Education 20 (4): 45-57. https://doi.org/10.22176/act20.4.45 
Doris: No. I didn't want to be stuck in some office, and they didn't have too much to offer at that time. The field that I had planned on going into before I found out they had a band didn't have any openings . . .

Doris generously allowed me to make a digital copy of her scrapbook from her time in the WAF Band. As I scanned each page, I came across a picture that shows her being sworn in by the unit commander. Doris's uniform sleeve bears the number of chevrons indicating her rank as sergeant; she clearly is not a new recruitthe picture is dated 1961. The image was unambiguous evidence that she had reenlisted for an additional term in the same year she claimed to have been discharged "on a good note" because her "time was up." It appeared that Doris had lied to me about the facts of her separation from the Air Force.

The morning report ${ }^{6}$ from Doris's last day of service indicates that she was discharged in accordance with Air Force Regulation (AFR) 39-17, the regulation that authorized a discharge for airmen if they are unfit or unsuitable for duty. AFR codes are always accompanied by an additional separation designation number (SDN) that indicates the specific reason that the airman was deemed unfit. Doris's discharge papers, and those of sixteen others caught up in the first of two waves of involuntary separations that resulted from the investigation, are inked with the designation SDN 488, a code indicating a non-specific, generalized unfitness to serve. These airmen7 were dismissed from the military with a General Discharge Under Honorable Conditions, which is not the same as an Honorable Discharge, yet still entitled them to veteran's benefits if they were otherwise qualified.

At that moment in the interview, I was not aware that Doris was concealing the facts of her last days in the band. But as she went on with her story, she grew quieter, introspective. I did not dare interrupt. She continued with her thoughts and memories, reaching out to share her truth even if she did not share her facts:

She [the unit commander] said, "At least you won't be here at the end," and I said, "Well, I would like to be." . . . You want to be there for your friends. It was kind of like I was walking out, but yet they knew I wasn't. It was a sad time. I think I drove straight through. I just kept thinking about it and thinking about it and it just kept driving me. I didn't stop at all until I got home.

(long pause)

I know what they mean when they say life isn't fair-and they don't have to be just fair to me-fair to my friends too.

Nichols, Jeananne. 2021. Considerations of truth and fact in narrative analysis. Action, Criticism, and Theory for Music Education 20 (4): 45-57. https://doi.org/10.22176/act20.4.45 
Grace: Hide and Seek

When I attended the band's annual reunion for the first time in 2008, one of the highlights had been meeting Grace. Grace had been an enlisted leader of the band, beloved by all, and was a constant presence in my archive of pictures, articles, and military orders. She relished telling jokes and naughty stories with a garrulousness akin to that of a standup comedian. We recorded several interviews because I returned to her with questions at every band reunion for several years, but it was never a straightforward endeavor. I would ask my question, she might answer it, but then whipsaw into another completely unrelated topic. It was always a mystery to me how she selected the next anecdote to share, as it rarely had anything to do with the one that preceded it. Our conversations were always on her terms.

The morning reports revealed that she, too, had been investigated by the OSI and had been discharged, along with Doris, in the first wave of dismissals. When I saw her next, in 2013, I asked if she would be willing to talk to me about those last days. "Nope, I'm not talking about that part," she answered. "We don't have to talk about you specifically," I tried again, "just in general." Again, she refused. I knew that if I asked one more time, it would be one time too many.

Grace passed away shortly thereafter. As an act of remembrance, I went back and read the transcripts of our interviews from start to finish. And there, two thirds of the way through our very first conversation in 2008, when neither of us knew each other well, and sandwiched between two bawdy stories, was this:

Grace: I'll tell you something else that I haven't told anybody. Nobody knows this, and I'm not telling you the specifics about it. We were so disgusted when they were going to disband the band ... So anyway, they called me in to talk to me about it and about other things too, and I just lost it! I lost my cool and I told them exactly what I thought! I thought there were other reasons besides--if it were money--I forget what I said, but I wasn't looked on very kindly for that.

JN: Now who was talking to you?

Grace: The people who check you out to see if you're doing the wrong thing or whatever. I just lost my cool, and it was frowned upon I know, but I don't care; it didn't make any difference. I still got out with an honorable discharge, but I just thought they made a big mistake, a big mistake!

I had no idea, at the time, what Grace was talking about.

Sherrie Tucker, musicologist and noted scholar on women in jazz, coincidentally visited Grace in her home to interview her roommate, a well-regarded jazz musician. Grace and her roommate took great pains to make sure that Tucker saw the two separate bedrooms in their apartment. Tucker (2009) brooded over the

Nichols, Jeananne. 2021. Considerations of truth and fact in narrative analysis. Action, Criticism, and Theory for Music Education 20 (4): 45-57. https://doi.org/10.22176/act20.4.45 
incident in "When Subjects Don't Come Out," a chapter written for the book Queer Episodes in Music and Modern Identity. Contemplating Eve Sedgwick's observation that the specter of the closet shapes the daily lives of even the most open and out gay man or woman, Tucker wrote:

While the ... apartment with two beds may not necessarily point to a particular lesbian relationship that I can reconstruct from these shards of information, they do point, I believe, to the presence of the closet as a shaping factor in the lives of women who live nontraditionally, be it with a woman lover, a woman friend, a roommate, alone and unmarried, or on a bus with fifteen other women jazz and swing musicians (298).

And in the case of this study, fifty other bandswomen on an Air Force plane.

Grace's facts and truths about her experiences at the hands of the OSI are part of her closet, and she holds the door. She allowed a small moment of access when I did not know enough to question her further, and she closed the door, I assume, when she felt like I knew too much. Tucker's point, and one that I subscribe to, is that regardless of the facts about Grace's sexuality, her nontraditional path of becoming a career-oriented military musician and living for decades with a female roommate guaranteed that she felt compelled to present a set of facts influenced by the fear of self-disclosure or the fear of damaging assumptions by others.

\section{Shirley: Silencing the Truth}

I met Shirley in 2015. She had never attended any of the WAF band's previous seventeen reunions. But with the urging and support of her friends in the band over several years, Shirley decided to come. The other members had informed me that she had lived a difficult life since leaving the service--never held a job or stayed in a relationship for long. Her countenance communicated a mix of stress, sadness, and anger.

The morning reports revealed that Shirley was part of the second wave of discharges during the waning days of the WAF Band. The records for these women bear a different separation designation code, SDN 257 Homosexual, from the women in the first group. SDN 257 Homosexual meant that the OSI had more than gossip and innuendo against the member. I gingerly approached her for an interview. She agreed, telling me that her band friends had said I was okay. She was ready to talk. And when I asked her how she left the band, her story unfolded like this:

Nichols, Jeananne. 2021. Considerations of truth and fact in narrative analysis. Action, Criticism, and Theory for Music Education 20 (4): 45-57. https://doi.org/10.22176/act20.4.45 
So, when I walked in after I was called into OSI, I sat at the table, and I think there were two people in there, but the light they put in my eyes was so bright I couldn't see even around the room. They had lights like this, two of them, right into my face, and so what I did was I told the truth ... my partner and I talked about it because neither of us are good liars, and we decided to just get it over with. I never mentioned another name but hers.

I had nothing in my locker-no letters, no whatever they were looking for. I had nothing. They called me in again to make sure of what I had said and sort of checked it off, and it was done just as fast as that. And the same for my partner. We had to have physical exams on getting out, and they gave us rectal examslaughed the whole time they were doing it. Then a doctor came in the room-it was a male doctor-and another male doctor, and they were making horrible jokes. OSI escorted me off the base and scrubbed off my decal at the gate, and there we were.

We wound up in LA. We were in our apartment and at two or two-thirty in the morning, somebody knocked on the door. It was my partner's father ... it was the first time I'd ever met him. He had two guys with him that looked right out of The Godfather. He made her pack her stuff. She tried to look around and see if she had left anything, and he said, "Forget it, I'll buy it for you!" Then he left with her, and the two men stayed with me for a few minutes and told me that if I ever tried to contact her it would not end well for me, and that's the last I ever saw or heard from her.

It is beyond the scope of this paper, not to mention well beyond the scope of my scholarly abilities (such as they are), to offer a psychological assessment or analysis of Shirley's account of her horrific experience. Even so, I noticed that she constructed her story as a linear recitation of events, a litany of facts. Not once does she turn to the subjective, narrate her feelings, or speak of the harm this trauma surely inflicted. Paradoxically, the import of her truth is inexorably heightened by its absence, amplified by her silence.

\section{The Choreography of Fact and Truth}

In the book State Repression and the Labors of Memory, Jelin (2003) considers the nature of memory and the challenge it presents for social science researchers who seek stories from persons who were targeted, traumatized, or oppressed-particularly by the state. She characterizes memory as important, productive labor, distinctive to the human condition. Whether by an individual or a collective, memory work can involve a number of tasks, such as reckoning with a past that invades and disrupts the present, overcoming silence to ensure the past remains in memory, or struggling to see that an interpretation of the past becomes the preferred one (50).

Nichols, Jeananne. 2021. Considerations of truth and fact in narrative analysis. Action, Criticism, and Theory for Music Education 20 (4): 45-57. https://doi.org/10.22176/act20.4.45 
From this perspective, the WAF Band members have been on a $60-$ year mission of memory labor-some working to remember, some working to forget, some fighting for a particular narrative of the band to be promoted, some worrying that aspects of their past might besmirch the sheen of their legacy. The work of memory, the ongoing tension between remembering and forgetting, appears to create a choreography of facts and truths, a dance that reveals and conceals. As Jelin (2003) states:

Both radical positivism and radical constructionism deploy discourses that seek closure, in other words, a definitive answer that approximates "truth." Yet with respect to the issues that concern us here-characterized as they are by traumas and ambiguities, silences and excesses, by the search for objectivity combined with ethical and affective commitments-the tasks of search and research may perhaps be situated in a "third position":... a conception of history as tensely involving both an objective reconstruction of the past and a dialogic exchange with it that involves not only the processing of information but also affect, empathy and questions of value (35).

Like Tucker (2009), I brooded over my researcher notions of entitlement to these bandswomens' facts and my desire to reinterpret their truths. I may see their trauma as honorable, as unjust suffering on the long road towards women's equality, but they see the ending of a band they loved through lenses of fear and shame. This is an irresolvable tension that shapes their telling of the tale as well as my ability to hear it.

In the admittedly murky waters of narrative analysis, taking up Jelin's "third position," wherein the search for the objective is partnered with, even tempered by, the quest for the subjective, is one way to navigate the shoals on the rivers of human storying. As Patai (2001) succinctly observed, "Not all statements are accurate, but all statements are meaningful" (76). In some stories, facts and truths may be independent, absent, or in conflict, and it is tempting to dismiss these accounts as unreliable. But under the surface, facts and truths are dialogically bound together. Narrative inquirers need not despair when participant stories are messy and contradictory, or even when the storyteller refuses to speak, for these moments often yield some of the most profound insights for those attuned to this connection.

Nichols, Jeananne. 2021. Considerations of truth and fact in narrative analysis. Action, Criticism, and Theory for Music Education 20 (4): 45-57. https://doi.org/10.22176/act20.4.45 


\section{About the Author}

Jeananne Nichols is an associate professor of music education at the University of Illinois in Urbana-Champaign. Drawing upon narrative inquiry and other qualitative research designs, Dr. Nichols' research highlights the lived experiences of persons whose voices may otherwise be muted in the prevailing discourses of music and music education. Her specific projects include participatory music experiences with incarcerated youth, the United States Air Force WAF Band, and the experiences of LGBT students in school music. Her work has been published in the Journal of Research in Music Education, The Bulletin of the Council for Research in Music Education, Research Studies in Music Education, The Music Educator's Journal, The Mountain Lake Reader, and The International Journal of Education and the Arts.

\section{References}

Blumenfeld-Jones, Donald. 1995. Fidelity as a criterion for practicing and evaluating narrative inquiry. International Journal of Qualitative Studies in Education 8 (1): 25-35. https://doi.org/10.1080/0951839950080104

Denzin, Norman.K., and Micheal D. Giardina. 2016. Qualitative inquiry and the politics of evidence. New York: Routledge.

Hodkinson, Phil M, and John K. Smith. 2005. Relativism, criteria, and politics. In The Sage handbook of qualitative research, edited by Norman K. Denzin and Yvonna Lincoln, 915-32. Los Angeles: Sage Publishing.

Jelin, Elizabeth. 2003. State repression and the labors of memory. Minneapolis: University of Minnesota Press.

LeCompte, Margaret D. 1993. A framework for hearing silence: What does telling stories mean when we are supposed to be doing science? In Naming silenced lives: Personal narratives and processes of educational change, edited by Daniel McLaughlin and William G. Tierney, 9-27. New York: Routledge.

Lubet, Steven. 2018. Interrogating ethnography: Why evidence matters. New York: Oxford University Press.

Patai, Daphne. 2001. Whose truth? Iconicity and accuracy in the world of testimonial literature. In The Rigoberta Menchú controversy, edited by Arturo Arias and David Stoll, 270-87. Minneapolis: University of Minnesota Press.

Nichols, Jeananne. 2021. Considerations of truth and fact in narrative analysis. Action, Criticism, and Theory for Music Education 20 (4): 45-57. https://doi.org/10.22176/act20.4.45 
Stauffer, Sandra L. 2014. Narrative inquiry and the uses of narrative in music education research. In The Oxford handbook of qualitative research in American music education, edited by Colleen M. Conway, 163-85. New York: Oxford University Press.

Tucker, Sherrie. 2009. When subjects don't come out. In Queer episodes in music and modern identity, edited by Sophie Fuller and Lloyd Whitesell, 293-310. Urbana: University of Illinois Press.

\section{Notes}

${ }^{1}$ Each participant has signed a standard consent letter as required by IRB and waived their confidentiality and anonymity for this historical study; nonetheless, I have decided not to use their actual names and to obscure details that might reveal their identities in this paper.

2 The WAF Band held their first reunion in 1997 and continued meeting annually, with a few exceptions, until 2018. The main focus of their gatherings was to perform at least two concerts, one for the public and one for veterans in care. I began attending in 2008, and in 2011, I was invited to serve as emcee for their concerts. I continued in this role through their final performance at the Kennedy Center for the Performing Arts, Washington, DC on August 29, 2018.

3 The corrected details are that Marilyn attended an annual meeting of Air Force bandmasters held at Chanute Air Force Base in Rantoul, Illinois and the picture of her and the male tuba player was published in the March-April 1952 issue of The Instrumentalist magazine.

4 A selection of laudatory reviews is featured on the publisher's web catalog entry for the book at https://press.uchicago.edu/ucp/books/book/chicago/O/bo180 39324.html

5 The McCarthy Era roughly corresponds to the decade of the 1950s. Senator Joseph McCarthy is best known for a set of hearings he conducted accusing a large number of persons of disloyalty to the US Government. McCarthy's fears were also codified into laws and policies that outlawed communists and homosexuals from serving in the federal government and the military. These statutes remained in place well into the 1970s, long after McCarthy was censured by the US Senate in 1957.

${ }^{6}$ Air Force units were required to file a daily update, known as a "morning report," detailing their current manning and mission readiness. A section in these reports, available from the National Archives in St. Louis, Missouri, documents the personnel that joined or left a unit on that day.

Nichols, Jeananne. 2021. Considerations of truth and fact in narrative analysis. Action, Criticism, and Theory for Music Education 20 (4): 45-57. https://doi.org/10.22176/act20.4.45 
7 In military terminology, "airman" is an equivalent term to soldier (US Army), sailor (US Navy) and marine (US Marines) and is applied to any servicemember in the Air Force regardless of their gender identity.

Nichols, Jeananne. 2021. Considerations of truth and fact in narrative analysis. Action, Criticism, and Theory for Music Education 20 (4): 45-57. https://doi.org/10.22176/act20.4.45 